DOI https://doi.org/10.36059/978-966-397-207-7/1-29

\title{
DEVELOPMENT OF THE CONCEPT OF LOCAL SELF-GOVERNMENT IN THE UNITED STATES
}

\section{Berezhna K. V.}

In most modern countries, local affairs are known to be governed both through the organs of State administration, which act as a peripheral link of the State apparatus, and through representative organs. Actually, they implement the right to exercise local selfgovernment, envisaged by the constitutions of the developed democratic countries. Self-government bodies emerged in Europe in the times of developed feudalism as a direct counterweight to the absolute power of the center. Initially, these bodies were formed based on limited suffrage by wealthy citizens of the society, in whose interests serious voting qualification barriers (literacy, settled way of life and property) were set for ordinary citizens in the Middle Ages. As a result of the victory of the bourgeois revolutions, election of self-government officials in Europe, and then in the United States, was made more democratic, and self-governing bodies turned into close to the population structures that were in charge of activities of citizens.

When it comes to the national experience of the development of local self-government, it should be indicated that it began to take shape when the Ukrainian lands fell under the authority of Grand Duchy of Lithuania, where Magdeburg rights acquired legal force. It was when the legal basis for emerging of this phenomenon was created by the charters of medieval towns, and this became a certain way of making municipal form of self-government "legal", which eventually was embodied in Magdeburg rights. Unfortunately, the development of the national law of local self-government was suspended later on, and under new historical conditions, the 
democratic and legal Ukraine has to develop its own self-governing structures ${ }^{1}$.

The Ukrainian science accepted the following definition of the phenomenon of local self-government: it is "the political-legal institution of democracy, through which the management of local affairs in the lower administrative territorial units is exercised by selforganization of residents of a specific territory by agreement and with the assistance of the State"2. However, this definition is not complete and correct, because in terms of the implementation of the course of Ukraine to join the democratic community of European States, it is necessary to take into account the fact that in the Law of the European Union (EU), before all, it goes about the phenomenon of the "local democracy". European science of municipal law relies on the normative definitions of such act as "The European Charter on Local Self-Government of the Council of Europe". From its content, it follows: "Local self-government outlines the right and the ability of local authorities, within the limits of the law, to regulate and manage a substantial share of public affairs. In a local democracy this right is conferred to councils or assemblies composed of members freely elected by secret ballot and directly accountable to their own local constituency. This adheres to the principle of subsidiarity, which ensures that problems are addressed by those institutions and civil society groups that are most competent and closest to citizens"3.

As far as the approach of American scientists to this phenomenon is concerned, they are citizens of the only State in the world, in the constitutional law of which it was reflected that America has never been a social state and will never be such a state. As a result, American specialists in local self-government do not take much care of the problems of citizens seeking to participate directly in the administration of local affairs, and therefore, without any romantic

${ }^{1}$ Калашников В.М. Хмельников А.О. Принципи місцевого самоврядування: європейські стандарти та національне законодавство // Держава $i$ права. Збірник наукових праць. Юридичні і політичні науки. Спецвипуск. Київ-Дніпро: Інститут держави і права НАН України, 2003. - С. 321-323.

2 Великий енциклопедичний юридичний словник / за ред. Ю. С. Шемшученка. - Київ : Юридична думка, 2007. - 990 с., с. 478.

3 Bulmer E.W. Local democracy. - URL: https://www.idea.int/publications/ catalogue/local-democracy 
attitude to manifestation of democracy of a local kind, they very briefly state the following: "Local democracy is the self-government of cities, towns, villages and districts by democratic means typically, but not exclusively, through elected mayors, councils and other local officials». If so, the following should be stated: «Local self-government outlines the right and the ability of local authorities, within the limits of the law, to regulate and manage a substantial share of public affairs. In a local democracy this right is conferred to councils or assemblies composed of members freely elected by secret ballot and directly accountable to their own local constituency. This adheres to the principle of subsidiarity, which ensures that problems are addressed by those institutions and civil society groups that are most competent and closest to citizens"

There is no doubt that the development of local self-government in Ukraine must be reinforced by the legal experience of democratic countries, where the right of local communities to take appropriate part in public government is stipulated at the constitutional level. Unfortunately, the national experts in the problems of local selfgovernment focus their attention only on European municipal law. It is natural, since our State seeks to join the European Union. Not by chance the Ukrainian legislation reflects the European experience in solving the problems of local communities, referring to the main provisions of the European Charter of Local Self Government. Nevertheless, the four-century development of local self-government in the United States, which dates back to 1620, when the so-called "pilgrims" signed the famous "Mayflower Compact", deserves great attention. In the text, the following is announced: "In the name of God, Amen. We whose names are under-written, the loyal subjects of our dread sovereign Lord, King James, by the grace of God, of Great Britain, France, and Ireland King, Defender of the Faith, etc.

Having undertaken, for the glory of God, and advancement of the Christian faith, and honor of our King and Country, a voyage to plant the first colony in the northern parts of Virginia, do by these presents solemnly and mutually, in the presence of God, and one of another, covenant and combine ourselves together into a civil body politic, for

4 Local democracy/ - URL: https://www.alda-europe.eu/public/publications/ 168-EPD-Fact-Sheet-Local-democ racy-1.pdf 
our better ordering and preservation and furtherance of the ends aforesaid; and by virtue hereof to enact, constitute, and frame such just and equal laws, ordinances, acts, constitutions and offices, from time to time, as shall be thought most meet and convenient for the general good of the Colony, unto which we promise all due submission and obedience. In witness whereof we have hereunder subscribed our names at Cape Cod, the eleventh of November [New Style, November 21], in the year of the reign of our sovereign lord, King James, of England, France, and Ireland, the eighteenth, and of Scotland the fifty-fourth. Anno Dom. 1620» ${ }^{5}$.

The text of this legal act is interpreted by modern-day specialists in the constitutional law of the United States as the first normative source of American constitutionalism. However, it was a very controversial document, the analysis of which, conducted by Ukrainian researcher V. M. Kalashnikov in his paper "The Conceptual Framework of the "Mayflower Compact" and Modern Constitutional Law of the United States" gives grounds to state only one thing - in the 1620, the colonists of New Plymouth laid the foundations of American local self-government, though the mother country provided them with the right to do it only some time later. It is also important that the countdown of the theories of the development of local self-government in America began from this compact $^{6}$.

\section{Evolution of theories of law of local self-government of the united states}

Needless to say that without an analysis of the legal principles of local self-government that have been ingrained in America for four centuries of the development of this country, it is not possible to find the right way to the formation of the national system of local selfgovernment, which ensures democratic solutions to the problems of

\footnotetext{
5 Text of Mayflower Compact. - URL: http://www.pilgrimhallmuseum. org/mayflower_compact_text.htm

6 Калашников В.М. Концептуальні засади «Угоди на «Мейфлауєрі» і сучасне конституційне право США // Держава $i$ право. Збірник наукових пращь. Юридичні $i$ політичні науки. - Київ: Інститут держави і права НАН України ім. В.М. Корецького, 2005. - С. 472-478. 
local communities at their levels of public governance. This experience is impressive by the fact that four centuries of the development of American statehood demonstrated an impressive inseparable unity of the institutions of local governance, which were the heritage of British America, and local democracy, generated by the Americans after the Declaration of State sovereignty of the independent United States. This is pointed out by the known to the whole scientific world "Encyclopaedia Britannica", which provided the following description of local democracy of the United States, which largely coincides with a similar system that exists in Great Britain: "Municipality, in the United States is urban unit of local government. A municipality is a political subdivision of a state within which a municipal corporation has been established to provide general local government for a specific population concentration in a defined area. A municipality may be designated as a city, borough, village, or town, except in the New England states, New York, and Wisconsin, where the name town signifies a subdivision of the county or state by area. The municipality is one of several basic types of local government, the others being counties, townships, school districts, and special districts ${ }^{7}$.

The British Encyclopaedia should stimulate the interest of researchers to modern local democracy of the United States, but first of all, they have to deal with the structural peculiarities of this "building", stipulated in the Main Law of the United States, the Constitutions of separate states and other legal acts regulating the implementation of the public power locally. Obviously, the versatility of the approaches to understanding the essence of local selfgovernment is the result of a lasting impact on the theoretical and practical developments on the problem of the comprehensive concept of "power". This situation in legal science, public administration and social sciences is a consequence of the specified multidimensional phenomenon. The widespread use of the term "power" for the reflection of different phenomena in many areas leads to the fact that representatives of social sciences are forced to use the term "public" (social) power, although any power is public. The subsystem of

${ }^{7}$ Municipality local government. - URL: https://www.britannica.com/topic/ municipality 
public power is formed by every level of social integration that has certain mechanisms for identification and implementation of the will of the individuals composing it. Therefore, one should differentiate between the power of the world community, state power, municipal power and the power in citizens' communities.

This approach to the classification of subsystems of public power is maximally approximated to the external institutional level of their implementation in the theory and practice of the formation of local self-government bodies, which began to stand out of superior bodies of public power in the times of the transition of the countries in Europe from feudalism to early capitalism. All this stimulates scientific research in the field of studying the basic theories of the origin and development of the science of municipal law.

It is known that a systematic approach to providing local communities of the United States with managers, who competently solve problems of local self-government, began to be applied in America after World War II. Now, thirty-nine institutes of higher education grant diplomas in specialty "Development of local communities", what is more, seven institutions train Master degree students in this area. In addition, five areas of specialization appeared in this field, namely: 1) local community development planning; 2) economic development of local communities; 3) city problems; 4) development of agricultural regions; 5) local self-government. In this case, the scientific approach to understanding the problems of local self-government requires that American students should laboriously study the main theories of the origin and strengthening of local democrac ${ }^{8}$.

Since early bourgeois revolutions, local self-government in different states evolved within the boundaries, set by AngloAmerican and Roman-Germanic legal systems, which are characterized by different approaches to determining the content and features of legal regulation of the issues of local communities. Social scientific opinion regarding this problem has fallen into several areas, in the depths of which some of the theories of local self-government crystallized. They include the theory of free community, economic

${ }^{8}$ Муніципальне право України : підручник / за ред. М.О. Баймуратова. - К.: Правова єдність, 2009. - С. 99-100. 
theory, legal theory, political theory, the state and organic theory. All these theories are based primarily on the genetic features of selfgovernment in different countries.

Self-government is implemented in relevant institutional forms at all stages of the evolution of society. One should remember that throughout all the history of the civilized society, the tendency towards an increase in the share of central public administration in the system of public power has been strengthening, which resulted in absorption of self-government activities of territorial communities.

It should be specified that the government of medieval towns was rather conditional, since political and economic principles of the organization of a feudal society allowed only limited forms of realization of a self-governing capacity. And only at the time of formation of a bourgeois state did self-government as a centralized administration within any social system emerged. In addition, selfgovernment appeared only in one country in the world, in the United States that originally went through the development of bourgeois society, immediately after the British colonies, which were later destined to be transformed into an independent state, appeared in North Americ .

The theory of local self-government was created by the ideologists of the earliest bourgeois revolutions (English, Great French revolution, first American revolution), which are known as "enlighteners". Their task was to substantiate the right of bourgeois owners to create a new social type of the state - a bourgeois state. That is why the enlighteners sought to find out the sources of their concept by turning to the fight of the bourgeoisie for its own right through the operation of self-governing local communities ${ }^{10}$.

The main theoretical source of liberalism appeared to be the ideology of Enlightenment, which in the XVIII century experienced a great influence in the British colonial empire, due to the fact that the English revolution of the XVII century accelerated the development

9 Andrews Ch. M. Virginia: the Old Dominion. - Richmond: The Dietz Press, Inc., 1949. - P. 120.

${ }^{10}$ Caldwell R.G. A Short History of the American People. - New York; L.: Low, Marston and Company, 1925. - P. 111. 
of capitalist relations ${ }^{11}$. The Protestant Church also contributed to it. The Calvinist doctrine of definition and the Protestant ethic prompted by it led to wide spread of entrepreneurial spirit and thereby created a deep psychological foundation of capitalist civilization. England was the birthplace of the ideology of Enlightenment, which led to strengthening representative institutions that included local selfgovernment bodies. The experience of the mother country in dealing with local affairs of that time was transplanted to America ${ }^{12}$.

The most important foundations of the doctrine of local selfgovernment of the theoretical nature were laid down at the end of the XVIII century. The constitutional movement, accepting state constitutionalism as the political-legal system of a civilized state, pushed by the American and French revolutions, led not only to emergence of new forms of organization of state power, but also inevitably set the task of the local self-government conversion on the basis that was free from strong bureaucratic supervision. It is clear that this task had to be solved in the framework of the Enlightenment ideology, the prominent representatives of which were American enlighteners ${ }^{13}$.

The work of the English ideologists of the Enlightenment in the field of creation of the theoretical and practical foundations of local self-government was continued by Americans K. Kolden, B. Franklin and T. Jefferson. They relied on the doctrine of natural rights and freedoms, which included three mandatory components - life, liberty and property. An important component of the enlightening ideology appeared to be the theory of people's sovereignty and was closely associated with the idea of a social contract, the consequence of which was the emergence of civil society and the state that had to protect natural and inalienable human rights.

The teaching of enlighteners about the principles of the new state and political system, the foundation of which was the doctrine of

11 Byrne T. Local Government in Britain. Everyone's Guide to How it All Works. - L.: London University Press, 2000. - P. 300.

12 Калашніков В.М. Походження місцевого самоврядування в Сполучених Штатах Америки // Юридичний вісник. - Од.: ОНЮА, 2001. - № 2. - С. 107-112.

${ }^{13}$ American Philosophical Society, Library. Calendar of the Papers of Benjamin Franklin. - Vol. 1. - Film 54. - Reel 43, 85, 113. 
power distribution, was based on the theory of social agreement. The American enlighteners linked the practical implementation of this doctrine in life to the development of local self-government in the different forms that, first of all, would be suitable in the existing natural environment ${ }^{14}$.

Now we are looking for the forms of reaching the final result developed self-government. When addressing this issue, it is necessary to distinguish between local management and local selfgovernment, since at the present stage of development of the public power in different countries, it exists at two levels - state and selfgovernment power. It is clear that the process of solving local problems is mostly influenced by those state authorities that solve the complex of local problems under the supervision of supreme political power. However, self-government bodies, which may not be removed from the national processes, participate in these processes. This demonstrates the development of local democracy in the United States. Hence, the increased attention to theoretical developments of American scientists in this field of law and their practical implementation.

T. Jefferson, one of the "Founding Fathers" of the United States, the third President and the author of the Declaration of Independence of the USA stood created the sources of the theory of citizens' solving their own affairs through the bodies of the territorial community ${ }^{15}$. He was a great planter - slave owner, but was guided by petty bourgeois and democratic views on the development of the United States as a Republic of farmers. That is why in his paper "Notes on the State of Virginia", he formulated a view on selfgovernment of small communities, "the Republic in miniature" as the ideal form of statehood. Jefferson put forward the concept, according to which the municipalities were recognized as the fourth power that was controlled only by the law and by the court and was not subordinate to the government and its bodies in the centre and locally.

\footnotetext{
${ }^{14}$ American Philosophical Society, Library. Solomon Feinstone Collection of the American Revolution. - Reel 1, № 213, 219; Reel 2. № 888.

15 American Philosophical Society, Library. Presidential Papers Microfilms. Thomas Jefferson Papers. Jeneral Correspondence, 1761-1826. Account Books for the Years 1767-1770. Reel 58, Serie 4; Reel 60, Serie 11-12.
} 
It is enshrined in the Federal Constitution and the Constitutions of all States. The local self-government in Ukraine must develop in this direction $^{16}$.

The views of $\mathrm{T}$. Jefferson on self-government were especially interesting. He considered small communities as an ideal form of the development and functioning of democratic statehood. This conceptual approach gave birth to the concept of a "layer cake", according to which municipalities were recognized as the fourth power, controlled by the law and the court, but not subordinate to the Government and its bodies in the center and locally. Based on this, we can conclude that the idea of independence of local selfgovernment was a major theoretical achievement of the early bourgeois democracy ${ }^{17}$.

In the nineteenth century, great attention was paid to the system of self-government developed in the United States by the French statesman, historian and writer A. de Tocqueville. He visited the young American State and in his famous work "Democracy in America" wrote that the communal institutions play the same role for establishing independence as primary schools for science. The nation can form the free government without public institutions, but it will gain the true spirit of freedom.

One of the central ideas in the concept of A. de Tocqueville is the idea that the original source of power is not a State, and not even the people, but rather voluntarily united individuals who control their own affairs. Under these circumstances, people form real civic awareness, sense of responsibility, ability to agree their interests with those of their neighbors and coordinate them. The ideal of Tocqueville was the society that functions as a set of free and selfgoverning associations and communities. He saw the real alternative

16 Jefferson Th. Writings : Autobiography / Notes on the State of Virginia / Public and Private Papers / Addresses / Letters / [ed. by M.D. Peterson - New York City : Library of America, 1984. - 1600 p.

7 Eggleston E. The Beginners of a Nation. - N. Y.; L.: Appleton and Co., 1927. - P. 351. 
to the state autocracy in the systems of administration based on the principles of decentralization and self-government ${ }^{18}$.

It is known that after the defeat of the European bourgeoisdemocratic revolution in 1848-1849, local self-government became an object of scientific research of the lawyers in those countries that did not implement the course to the final transition from the semifeudal economic and political system to capitalism. The German specialists are especially prominent among the specified scientists. Under their influence, this problem has attracted attention of Russian specialists in the State law, especially at the time when they had to consolidate the bourgeois reforms of the 60-70s of the nineteenth century, including the reforms of agricultural and town governance. Then, they managed to include the concept of autonomy of communities in dealing with local affairs of economic character to the "Complete Code of Laws of the Russian Empire" 19

A great contribution to scientific analysis of self-government, which originated as a result of the bourgeois reforms of the Government of Alexander III, was made by the lawyers of Kharkiv and Kiev universities, who found an appreciative audience in the form of democratically-minded students. Then the lawyers of Kharkiv and Kiev came to the conclusion that most scientific interpretation of the legal and organizational institution of the local self-government was offered by the Prussian lawyer R. Gneist. It is interesting that his research, which contributed to the development of the State law of the united Germany, helped American specialists in the Constitutional law to find specific opportunities to overcome the consequences of the Civil war of 1861-1865 through the development of the institution of local self-government ${ }^{20}$.

It should be pointed out that University professors tried to continue to look for opportunities for the development of local self-

${ }^{18}$ Tocqueville A. de. Democracy in America / [Translator - H. Reeve]. - A Penn State Electronic Classics Series Publication. - P. 71-78. - URL: http://seas3.elte.hu/ coursematerial/LojkoMiklos/Alexis-de-Tocqueville-Democracy-in-America.pdf

19 Панейко Ю. Теоретичні основи самоврядування. - Лв.: Літопис, 2002. C. 71-79.

20 Ashford D. British Dogmatism and French Pragmatism: Central-Local Policymaking in the Welfare State. - L.: 1982. - P. 12. 
government in the Ukrainian lands. To do this, they turned to "the theory of free community" of German scientists X. Zechariah and N. Gerber, who hoped that implementation of their theory would contribute to the development of the German Empire of Hohenzollerns. This theory was based on the postulates of the "natural right" of a person, put forward by the defenders of the "common human values", among which a decent place was occupied by American lawyers. According to them, the community by its nature has the right to their own functioning independently on the central power. It is based on the following: 1) public affairs are different from the state affairs; 2) community is an entity having special rights, existence of which excludes the state intervention in its affairs; 3) self-government officials are not representatives of the State, because they represent society ${ }^{21}$.

The transition of the industrialized countries of the world to this stage of development of the market economy, which was called by known economists, lawyers and politicians of the countries of the West "the epoch of imperialism", first of all, led to the emergence of the "legal theory of self-government" 22 . Its essence was that the selfgovernment bodies perform the functions of the state administration, but they are not bodies of the State as a legal entity, but rather of the local community. Therefore, the community itself, rather than state authorities can govern their affairs.

"The political theory of the local self-government" appeared in Russia during the bourgeois-democratic revolution in 1905-1907. Its author P. Stuchka, later the people's Commissar of Justice of the USSR, argued about the existence of antagonism of the people and the government, which can not deal with state and local affairs at the same time ${ }^{23}$. However, defenders of the polity of the Romanov and Hohenzollern empires, which had the major revolutionary movements at the beginning of the last century, put forth the "state theory', which is necessary for the success of the state in the fight against

21 The Merriam Webster Dictionary. - Springfield, Massachusetts, USA: Merriam-Webster, Incorporated, 2001. - P. 181.

${ }^{22}$ Jellinek G. Allgemine Staatslehre. - Berlin, 1914. - Heft 1. - S. 629-631.

23 Куйбіда В.С. Принципи і методи діяльності органів місцевого самоврядування. - К.: МАУП, 2004. - С. 21. 
revolutionists. The Germans L. Stein and R. Gneist and the Russians N. Lazarevsky and V. Bezobrazov considered local self-government as a part of the state, since any government of the public nature is considered the state government ${ }^{24}$. Today, this theory exists in England, where the regions have considerable autonomy. And the link of the United States with its former mother country makes some American experts share this opinion ${ }^{25}$.

A quick enumeration of the theories of local self-government convinces that it does not allow the one-dimensional vision. The studies of most modern supporters of the state nature of local selfgovernment are focused solely on foreign-institutional forms of the state arrangement within the constitutional and legal developments of the problem.

It is natural that an entirely different approach to the essence of local self-government was formed in the Soviet period. After the proclamation of the Soviet State, Stuchka proposed "the organic theory" because the transition to the state theory as a new social type of a state did not entrench yet. The "social class theory" emerged in the USSR over time. In Soviet times, the legal and organizational institution of self-government as a form of self-organization of local communities did not find its proper development, and the term "local self-government" stopped to be used. This is evidenced by a number of legislative acts of the USSR. It is clear that it is very difficult to transfer from the Soviet representative system to the modern Ukrainian self-government system that is developing in a contradictory and inconsistent way. And yet, the world experience of creating self-government bodies, including experience of the U.S., is acceptable to solve problems of our society.

The essence of each of these theories is based on genetic features of self-government in the different states. Analyzing the specified phenomenon, one should take into account the fact that the ratio of the state and local self-government may not be constant at all stages of the society development. It is especially difficult to establish these

24 Баймуратов М.А. Европейские стандарты локальной демократии и местное самоуправление в Украине. - Од.: Одиссей, 2000. - С. 5-9.

25 Жакке Ж.-П. Конституционное право и политические институты - М.: Юристъ, 2002. - С. 200-203. 
ratios at the stage of the development of the Ukrainian State, because we had no self-government in the form that is usual for developed countries.

All concepts of local self-government are characterized by significant historical conditionality and logical continuity. It is natural that scientific thought of every epoch of the development of a bourgeois society and appropriate state served to individual social transformation and had the imprint of historical, political and economic conditions for the emergence of this institution ${ }^{26}$. That is why it is possible to study the scientific views on the local selfgovernment in the United States as early as during their being under the jurisdiction of England only from the positions of historical and logical sequence of their appearance. A local community as an entity can be given only rights, rather than power. Regulation of activity of local government entities by the state is implemented by using the commonly acceptable type of legal regulation. The state determines the legal boundaries of self-government activity, provides it with financial resources and uses, where necessary, the mechanisms for forced implementation of its decisions.

The concept of "self-government" describes the degree of participation of the social community in relationship of the administrative character. It is a form of the public-administrative regulation by a group of individuals united by common interests as a result of the compact living on a certain territory, their own vital activity at the level that can not be ensured by the centralized state administration $^{27}$.

Given the international experience, including that of America, of the development of local self-government, we will note that by local self-government one should imply the system of bodies and officials (in the first place, elected officials), conditioned by the state in the framework of current legislation, which exercise local selfgovernment on a specific territory, for which the general state legislation established the degree of autonomy and independence

${ }^{26}$ Chandler J.A. Local Government Today. - Manchester: Manchester Univercity Press, 1996. - P. 181.

27 Калашников В.М. Організаційно-правові засади місцевого управління i самоврядування в зарубіжних країнах. Монография. - Дн.: Пороги, 2009. - С. 7-8. 
regarding state authorities. Self-governing bodies possess the necessary competence in dealing with the major state affairs and local issues that were passed to them. They operate taking into account specific features of the territory, its economic, social, ethnic, geographical, historical and other features, when it is necessary to replenish the local budget by collecting local taxes and establishing different duties, as well as during management of municipal property based of national legislation and their own statutory and other regulatory legal acts.

\section{Modern state of science of municipal law of the USA}

After World War II, the principles of subsidiarity, decentralization and regionalization were developing in the United States. The last two principles became the basis of the home state policy. The main focus of the subsidiarity principle is clear: after the defeat of fascism, contrary to the democratic centralism of socialist states, it was necessary to protect the autonomy of an individual and the right to self-government of lower political units. Subsidiary of power organization was contradicted to the authoritarianism of a centralized state. It guarantees its citizens freedom and independence, local and regional self-government. Profound changes in the socio-economic sphere led to the emergence of municipal theories related with the theory of social welfare state. The most prominent here is the theory of social service, under which municipalities were declared a tool which ensures and protects the interests of all classes and social layers. This theory provides an interpretation of the functions of municipalities as one of the manifestations of the super-class nature of the state of social welfare. It emphasizes the fact that the main task of municipalities is organization of population services.

The development of the general welfare state, expansion of the range of services provided to citizens had a double impact on functioning of local government. On the one hand, the role of local authorities in providing services to the population increased, which has stimulated the interest of the American States in the effectiveness of local self-government, on the other hand, intensified the centralization of the tax system, control of the center over the 
activities of local administration, especially the $\operatorname{cour}^{28}$. The evolution of local self-government of the United States strengthened the state nature of municipal institutions, having connected local issues with general American ones, put municipal institutions in administrative and financial dependence on the government and ministries. That is why the modern municipal theory of the United States proves that self-government incorporates the elements of the statehood and those of public basis ${ }^{29}$.

It is known that American specialists when analyzing the features of the legal enforcement of the institution of local self-government face the difficulties related to the fact that they still have to operate several definitions of this phenomenon at the same time. Among these definitions, there are "local self-government", "local administration", "municipal administration" and even "municipal management", which is the same as the previous definition. In this case, the term "local government", which in literal translation means "local administration" is used for the systemic definition of selfgovernment. Thus, the term "local government" is used in the work of B. Bernham "Introduction to Law and Legal System of the United States", though the term "self-government" is not the same as the term "government". This is pointed out by the Constitutions of certain American states, where it is explained that it is indicated that "selfgovernment' is a special political and legal capability of the population of cities in the United States ${ }^{30}$.

Therefore, in the science of the United States, there is inconsistency on how to determine the right of local communities to govern local affairs. However, even though the scientists of Ukraine and the United States use and ambiguous approach to the notions of "local government" and "local self-government", it is possible to point out that in our legal system it is necessary to denote the process

${ }^{28}$ Муніципальне право України: підручник / [за ред. М.О. Баймуратова]. К.: Правова єдність, 2009. - С. 112-123.

29 Калашников В.М. Зародження концепції правовой державності у Сполучених Штатах Америки // Держава та регіони. Науковий журнал. Запоріжжя: ЗІДМУ, 2001. - N 1. - С. 29.

${ }^{30}$ Burnham W. Introduction to the Law and Legal System of the United States (Coursebook). - Eagan, Minnesota West Academic Publishing, 2011. - P. 28. 
of exercising administration by public power bodies, which are built on the principle of representative democracy, by the term "local selfgovernment". It will be used not only in the sense of the institution of jurisprudence, but also to define the process of power implementation by government bodies of territorial communities. Other local authorities have to generalize the notion of "local executive bodies".

One of the important features that characterize contemporary American municipal science is "methodological revolution". It meant the acceptance of interdisciplinary approach (methods of sociology, political science, psychology, and social psychology, anthropology, law and public administration and other Humanities and quantitative research methods $)^{31}$.

In its stream, "new social", "new economic", "new political", "new labor" and many other "new" trends and schools originated, in the framework of which the researchers studied the features of statebuilding in the United States associated with the initiative of local communities regarding the solution of local problems. These schools and trends deserve attention because they claim to overcome subjectivity and voluntarism in social sciences, including those related to self-government development issues. Unfortunately, the excessive use of the structural-functional method of analysis, inherent in political science and sociology, leads to mechanical description of the changes in self-governing structures throughout the whole existence of the United States. However, despite all the features inherent in these scientific trends and schools, their representatives quite justifiably set the boundary, which separates the local democracy from political power.

American science rather meticulously highlighted the features that are characteristic only of local government. First of all, it concerns the nature of local power. State power is sovereign, capable of reforming itself, whereas local power is the bylaw power, which operates in the manner and within the limits defined for it through law. Thus, local, from the standpoint of American scholars, self-

31 Орзих М.Ф., Баймуратов М.А. Международные стандарты местного управления: учеб. пособие. - Одесса: АО БАХВА, 1996. - С. 33-35. 
government is characterized by the features of both power (state), and public institutions. Scientists of the United States acknowledge that a significant part of the local community's interests coincide with the interests of state-organized societies, which is normal for any country. As a result, there are no natural prerogatives of local groups to deal with local affairs without the state interference. Implementation of local interests is an attribute of both institutions of local selfgovernment and the state ones. The only difference is in the extent of their participation in this process, which is adjusted by a complex social nature of local self-government that is not a single-dimensional system. It combines a number of features specific to the state organization and inherent in a civil society, and therefore, it should be considered as a special institute in the system of a society ${ }^{32}$.

The role of self-government bodies is determined by the fact that in everyday life, citizens of almost all modern countries of the world constantly experience the consequences of the activities of these bodies, because the main feature of these structures is independent solution of a wide range of practical issues, referred to their power. Self-governing structures affect the creation of condition to ensure the vital activity of the population on the relevant territorial unit, although the main direction of socio-economic activity is determined by political authorities of the state. On the other hand, the fact that self-government bodies are related by organizational unity, endowed with powers concerning the ownership and disposal of municipal property, conclusion of contracts, disposal of the local budget. That's why under conditions of market economy, self-government is locally maintained and protected by the majority of the population of any country with the democratic political orde ${ }^{33}$.

Lawmakers, who create the legal basis for the operation of local self-government, come from the fact that the participation of citizens in the administration of public affairs can be directly implemented

32 Васильев В.И. Муниципальное управление: конспект лекцій / В.И. Васильев. - Ниж. Новг.: Изд. О.В. Гладкова, 2000. - С. 11.

33 Dillon J. Commentaries on the Law of Municipal Corporation. - Boston: Viking Press, 1991. - P. 13. 
only at the local level. In this case, it is obvious that the existence of local associations, endowed with real administrative powers, enables providing such administration, which would be most effective and closest to the needs of the population of a given territory community. Effectiveness and influence of local self-government bodies in different countries reflect the degree of democracy of the existing political regime.

Local self-government in the United States acquired the modern democratic character only after the end of World War II. Besides, the specified process has a positive impact despite the attempts of selfgovernment officials to actively use local authorities as an additional tool for the development of national administration systems. Such a policy is smoothed in the western countries by the application of the new principle of institutional organization of the state and society the principle of subsidiarity. It is based on the fact that a higher level of governing implies for the appropriate public officials certain possibilities of intervention in the action of government officials of a lower level of power executive activities only when the latter are not capable to implement independent effective administration of the society affairs. The direct application of the principle of subsidiarity implies the need for mandatory consideration of its practical effects on the distribution of powers. But it contradicts the basic principles of local self-government of the United States, where subsidiarity is not the principal but an additional problem-solving tool of local arrangement ${ }^{34}$.

The methods of research into the main problems of the American state formation in the area of the separation of the state and local affairs, the ratio of political power and self-government bodies have always been a scalpel for the American specialists, with which they operated the facts that attracted their attention. Each of these specialists has his own specific methods of using such a tool for comprehension of the self-government specifics, but they all must

${ }^{34}$ Game C., Leach S. Political Parties and Local Democracy // Local Democracy and Local Government. - N.Y.: McMillan, 1994. - P. 127-149. 
follow certain priorities for their work, which were provided by the political elite of the United States.

Interrelations between representatives of the official ideology of the United States are sometimes contradictory. They may include frequent sharp debates about the place of America in the world and on its internal development, including those in the field of solving local problems by territorial communities that have acquired now special weight as a result of the international financial crisis. A variety of ideological trends in the United States are the "left" and "right" wing radicals, conservatives and neoconservatives, liberals and neoliberals, libertarians and traditionalists ${ }^{35}$.

These trends have internal differentiation, which creates in people, who are not familiar with the essence of ideological and political realities of the United States, the idea of existence of the ideological "pluralism" there. But behind the expansion of ideological liberty, there hide the constraints of ideologists of the "American way", their firm belief in its uniqueness and the advantage that is reflected in different social sciences, including those, the research object of which is American local self-government. Assessments of the American experience in this sphere of life of the citizens are given by lawyers, sociologists, political scientists, economists, philosophers, historians and politicians. In the modern United States, it is possible to observe a revival of the ideological principles of the "golden age" of the statehood, which remained in the last century. America is clearly trying to "revive itself" on the basis of a return to the "virtuous" law and morality of the past and hence follows the great interest in the history of the United States, including the history in the field of local self-government.

The indicated approach to the analysis of the essence of American local self-government does not seem to allow other interpretations, but this is not quite true. Indeed, the United States, their home and foreign policy attract very close attention, and it is not accidentally. They act so far as the leading capitalist country that, according to its

${ }^{35}$ O'Brien S. G. American Political Leaders: from Colonial Times to Present. Santa Barbara: ABC-CLIO, Inc., 2001. - P. 33. 
traditions, declares the advantages of the "American way of life", seeking to make it a model for the whole world. However, American men of power do not have and did not have any special doubts regarding the choice of the means for the implementation of such a policy. Promoting American "values", they rely on an enormous "ideological army", which includes professional social scientists and journalists. Interrelations between the representatives of the official ideology of the United States are sometimes very contradictory, and there are many sharp debates about America's place in the world and the ways of its internal development, which have now acquired special weight due to the impact of the international financial crisis. The range of modern ideological-political trends in the United States is also diverse: conservatives and neoconservatives, liberals and neoliberals, libertarians and traditionalists, left and right radicals.

Leading positions in modern American historiography of local self-government of the United States are held by the apologetic direction, which recognizes "American exclusivity" as the cornerstone of its science. It is intended to substantiate the "superiority" of the American people, who allegedly carried out a unique democratic experiment to address local issues by means of self-government from the time when the ancestors of modern Americans were under British jurisdiction.

The school of "consensus" ("conflict-free") had a leading role in the apologetic science of public administration and local selfgovernment of the 50s in the last century. It was deeply influenced by the liberal-bourgeois idea, the positions of which were intensified due to the victory of the United States in the cold war. The constant alternation of liberal and conservative political cycles, which are characteristic of modern science of the United States, were best highlighted by Arthur M. Schlesinger, Jr. in "The Cycles of American History" (1986). He claimed that the "struggle between capitalist values - immunity of private property, maximizing profits, the cult of free market, survival of the fittest, and democratic values, such as equality, freedom, social responsibility and shared well-being" is going on in America. That is why, in his opinion, a great role in the United States is played by local self-government as an institution of 
democracy, and there are no irreconcilable contradictions between private initiatives and functioning of local communities, because in America, capitalism involves democracy and democracy involves capitalism $^{36}$.

It should be pointed out that at the end of the era of dominance of Marxist ideology, a number of scientific studies of the peculiarities of local self-government in the United States appeared in the USSR. The authors of these works rejected categorically negative assessments of local self-government there and the works by American specialists in the field of life of their fellow citizens. They opposed the dogmatic positions about the impossibility of successful adaptation of capitalism to the needs of social progress. However, such a worldview leads a part of scholars to the short-sighted idealization of the values of Western civilization, which manifest themselves at the lower level of territory communities. In their interpretation, the United States appear as an ideal of political democracy and social justice, strengthened through the activities of local self-government bodies $^{37}$. But life requires that the Ukrainian specialists in the local self-government should direct their efforts to strictly scientific objective study of the most important problems in the development of local self-government. If so, it should be remembered that American literature on the specified problem belongs mainly to the liberal direction of its studying.

In American municipal science, there is a comparatively small critical direction, which reflects the ideological position of the bourgeois and petty-bourgeois radicalism. Its chief apologist for a long time was the "progressist" school, the research interests of which focused mainly on the analysis of American state-building in the era of declaration of the United States independence, which was closely related with local self-government. Its founders including $\mathrm{Ch}$. Bird, V. L. Parrington, A. Schlesinger, Sr., put forward a fruitful thesis

\footnotetext{
${ }^{36}$ Schlesinger A.M. The Cycles of American History. - N.Y.: Houghton Mifflin Harcourt, 1999. - P. 34.

37 Калашников В.М. Генеза конституційного права США // Правова держава. Щорічник наукових пращъ. - Вип. 10. - К.: Ін. держ. і права, 2001. C. 549-555.
} 
about the existence of acute state conflicts in the American history, the highest expression of which were, in their interpretation, two American Revolutions. They considered the further development of local self-government as one of the results of these revolutions ${ }^{38}$.

The "radical school" was developed within the framework of the critical direction in the United States in the 60-80s of the past century. Its representatives were under the influence of the critical directions of modern Western philosophy and sociology, from existentialism and the "Frankfurt School" to youth left-radical counterculture. Radical specialists in social sciences felt the impact of historical materialism. That is why they called themselves Marxists, although they did not recognize the need for a revolutionary transformation of capitalism. These scientists in some way used the method of historical materialism that contributed to the in-depth study of the sources of the local self-government.

At the end of the last century - at the beginning of this century, it seemed that in the science of the municipal law of the United States, there settled all the basic ideas of what is the nature of regulatory securing the rights of local communities of the United States to solve the problems of local life through the implementation of power administrative functions of their councils and mayors. American and English researchers, such as D. Ashford, T. Byrne, J.A. Chandler, J. Dillon, J.S. Holcombe R.G., Leach, D.J. Lacombe. J.A. Pica, J. Stewart, W.D. Valente, P. A. Watt and others, who together developed the Anglo-American science of municipal law, wrote about it. Here, they followed the concept of the guru of American liberals R. Hofstedter, who as early as in 1948 prophesied in his work "American Political Tradition" if the prosperity of all power institutions in America, including local authorities, is everlasting ${ }^{39}$.

Thus, at first glance, the system of scientific knowledge about the legal basis of the American local self-government, developed by

${ }^{38}$ Hartz L. The Liberal Tradition in America. - Eugene; Oregon: Harvest Books, 1991. - P. 5.

${ }^{39}$ Hofstadter R. The American Political Tradition: And the Men Who Made it. New York City: Vintage Books Publishing, 1989. - 560 p. 
Anglo-American researchers had to be fairly stable for many decades. Nevertheless, as early as in 1987, the well-known researcher of public legal policy of the United States M. Gottdiener warned in his monograph "The decline of Urban Policy" against such poorly grounded ideas. And he was right, because the revolutionary transformations, which were caused by the epoch-making crisis of the geopolitical "world arrangement structure, are now going on in the state legal policy of the United States. Like in the period of the Great depression when President F. D. Roosevelt initiated the "new course", it again started in America. There was a mismatch of the declared goal of general welfare and the resources that were in possession of the United States and other developed countries. That is why President D. Trump started the economic, political and social reforms that resemble an earthquake. The current leader of the United States gave the place in there reforms to the local self-government, which largely will be weakened because no sufficient funds for supporting the financial foundation of local self-government at least at the previous level were not found in the budget of the richest state in the world.

It is therefore not surprising that, as the American scientist M. Hendrix, the author of the research "The case of local selfgovernment", is writing, they actually got lost and demonstrated that they cannot yet grasp the essence of D. Trump's ideas regarding local democracy. They are studying legal philosophy of D. Trump and make very "brief" conclusions on this matter. The essence of their speculations is that strong traditions of local self-government in the United States gradually began to be pushed off by considerations of efficiency and rationality, due to which it is necessary to discard the models of functioning of local institutions of power, which do not live up to the corresponding expectations. However, their prediction of further destiny of American local self-government is shaky, because they understand that only the Government of the United States will "instruct" the governments of the separate states on the improvement of the legal framework of local self-government, and in the near future, states may have to cope with the aftermath of a 
serious load of problems that was laid on them by President D. Trump.

\section{CONCLUSIONS}

The development of local self-government has been going on along with the development of the central power and administration for four centuries of the development of American statehood in this country. Its principles were generated by the ideologues of American enlightenment, who largely borrowed the experience of solving this problem from the European science. However, these ideas have acquired a purely American face in the American soil. Actually, B. Franklin, J. Washington, T. Jefferson and other leaders of the American revolutionaries bequeathed it to their successors. On the waves of the victorious war for the independence of the United States, they began to form a new political and economic system of this country, in which the place for new principles of local selfgovernment was found.

The modern American science of municipal law and administration is diverse. Leading positions in it are held by the apologetic direction which recognizes "American exclusivity", "superiority" of the American people, who allegedly carried out a unique democratic experiment to address local issues by means of self-government. The school of "consensus" ("conflict free") that followed the liberal-bourgeois idea was the leader of the apologetic science of local self-government. Along with this, in the modern American science there is a critical direction that reflects the world outlook positions of petty-bourgeois radicalism.

At the end of the last century - at the beginning of this century, it seemed that in the science of the municipal law of the United States, there settled all the basic ideas of what the nature of regulatory securing the rights of local communities of the United States is. However, the globalization crisis led to the beginning of great economic, political and social reforms of President of the United States D. Trump, which have a significant impact on the American science of municipal law and administration. In the nearest future we should expect the "methodological revolution" in this science, the 
representatives of which are obliged to give response to the globalization crisis through the generation of new approaches to the analysis of the legal principles of local democracy in the country leader of the world community.

\section{SUMMARY}

The article deals with the peculiarities of development of the concept of local self-government in the United States. Evolution of theories of law of local self-government of the United States is investigated. The concepts of local self-government are characterized. Modern state of science of municipal law of the USA is analyzed. One of the important features that characterize contemporary American municipal science - "methodological revolution" is studied. It is determined that the principles of local self-government were generated by the ideologues of American enlightenment, who largely borrowed the experience of solving this problem from the European science. It is revealed that leading positions in the modern American science of municipal law and administration are held by the apologetic direction which recognizes "American exclusivity", "superiority" of the American people, who allegedly carried out a unique democratic experiment to address local issues by means of self-government.

\section{REFERENCES}

1. Калашников В.М. Хмельников А.О. Принципи місцевого самоврядування: європейські стандарти та національне законодавство // Держава $і$ права. Збірник наукових пращь. Юридичні і політичні науки. Спецвипуск. Київ-Дніпро: Інститут держави і права НАН України, 2003. - С. 321-323.

2. Великий енциклопедичний юридичний словник / за ред. Ю. С. Шемшученка. - Київ : Юридична думка, 2007. 990 c., c. 478.

3. Bulmer E.W. Local democracy. - URL: https://www.idea.int/ publications/ catalogue/local-democracy

4. Local democracy. - URL: https://www.alda-europe.eu/public/ publications/168-EPD-Fact-Sheet-Local-democracy-1.pdf 
5. Text of Mayflower Compact. - URL: http://www.pilgrimhallmuseum.org/mayflower_compact_text.htm

6. Калашников В.М. Концептуальні засади «Угоди на «Мейфлауєрі» і сучасне конституційне право США // Держава $i$ право. Збірник наукових праиь. Юридичні і політичні науки. Київ: Інститут держави i права НАН України ім. В.М. Корецького, 2005. - С. 472-478.

7. Municipality local government. - URL: https://www.britannica.com/topic/ municipality

8. Муніципальне право України: підручник / за ред. М.О. Баймуратова. - К.: Правова єдність, 2009. - С. 99-100.

9. Andrews Ch. M. Virginia: the Old Dominion. - Richmond: The Dietz Press, Inc., 1949. - P. 120.

10. Caldwell R.G. A Short History of the American People. - New York; L.: Low, Marston and Company, 1925. - P. 111.

11. Byrne T. Local Government in Britain. Everyone's Guide to How it All Works. - L.: London University Press, 2000. - P. 300.

12. Калашніков В.М. Походження місцевого самоврядування в Сполучених Штатах Америки // Юридичний вісник. - Од.: OHЮА, 2001. - № 2. - C. 107-112.

13. American Philosophical Society, Library. Calendar of the Papers of Benjamin Franklin. - Vol. 1. - Film 54. - Reel 43, 85, 113.

14. American Philosophical Society, Library. Solomon Feinstone Collection of the American Revolution. - Reel 1, № 213, 219; Reel 2. № 888 .

15. American Philosophical Society, Library. Presidential Papers Microfilms. Thomas Jefferson Papers. Jeneral Correspondence, 1761-1826. Account Books for the Years 1767-1770. Reel 58, Serie 4; Reel 60, Serie 11-12.

16. Jefferson Th. Writings : Autobiography / Notes on the State of Virginia / Public and Private Papers / Addresses / Letters / [ed. by M.D. Peterson - New York City : Library of America, 1984. - 1600 p.

17. Eggleston E. The Beginners of a Nation. - N. Y.; L. : Appleton and Co., 1927. - P. 351.

18. Tocqueville A. de. Democracy in America / [Translator H. Reeve]. - A Penn State Electronic Classics Series Publication. - 
P. 71-78. - URL: http:// seas3.elte.hu/coursematerial/ LojkoMiklos/ Alexis-de-Tocqueville-Democracy-in-America.pdf

19. Панейко Ю. Теоретичні основи самоврядування. - Лв.: Літопис, 2002. - С. 71-79.

20. Ashford D. British Dogmatism and French Prahmatism: Central-Local Policymaking in the Welfare State. - L.: 1982. - P. 12.

21. The Merriam Webster Dictionary. - Springfield, Massachusetts, USA: Merriam-Webster, Incorporated, 2001. P. 181.

22. Jellinek G. Allgemine Staatslehre. - Berlin, 1914. - Heft 1. S. 629-631.

23. Куйбіда В.С. Принципи і методи діяльності органів місцевого самоврядування. - К.: МАУП, 2004. - С. 21.

24. Баймуратов М.А. Европейские стандарты локальной демократии и местное самоуправление в Украине. - Од.: Одиссей, 2000. - С. 5-9.

25. Жакке Ж.-П. Конституционное право и политические институты - М.: Юристь, 2002. - С. 200-203.

26. Chandler J.A. Local Government Today. - Manchester: Manchester Univercity Press, 1996. - P. 181.

27. Калашников В.М. Організаційно-правові засади місцевого управління і самоврядування в зарубіжних країнах. Монография. - Дн.: Пороги, 2009. - С. 7-8.

28. Муніципальне право України: підручник / [за ред. М.О. Баймуратова]. - К.: Правова єдність, 2009. - С. 112-123.

29. Калашников В.М. Зародження концепції правовой державності у Сполучених Штатах Америки // Держава ma регіони. Науковий журнал. - Запоріжжя: ЗІДМУ, 2001. - N 1. C. 29 .

30. Burnham W. Introduction to the Law and Legal System of the United States (Coursebook). - Eagan, Minnesota West Academic Publishing, 2011. - P. 28.

31. Орзих М.Ф., Баймуратов М.А. Международные стандарты местного управления: учеб. пособие. - Одесса: АО БАХВА, 1996. - C. 33-35. 
32. Васильев В.И. Муниципальное управление: конспект лекцій / В.И. Васильев. - Ниж. Новг.: Изд. О.В. Гладкова, 2000. C. 11.

33. Dillon J. Commentaries on the Law of Municipal Corporation. - Boston: Viking Press, 1991. - P. 13.

34. Game C., Leach S. Political Parties and Local Democracy // Local Democracy and Local Government. - N.Y.: McMillan, 1994. P. 127-149.

35. O'Brien S. G. American Political Leaders: from Colonial Times to Present. - Santa Barbara: ABC-CLIO, Inc., 2001. - P. 33.

36. Schlesinger A.M. The Cycles of American History. - N.Y.: Houghton Mifflin Harcourt, 1999. - P. 34.

37. Калашников В.М. Генеза конституційного права США // Правова держава. Щорічник наукових прачь. - Вип. 10. - К.: Ін. держ. і права, 2001. - С. 549-555.

38. Hartz L. The Liberal Tradition in America. - Eugene; Oregon: Harvest Books, 1991. - P. 5.

39. Hofstadter R. The American Political Tradition: And the Men Who Made it. - New York City: Vintage Books Publishing, 1989. $560 \mathrm{p}$.

Information about the author: Berezhna K. V.,

Doctor of Juridical Sciences, Associated Professor, Head of the European and International Law Department Oles Honchar Dnipro National University 72, Haharin av., Dnipro, Ukraine 